\title{
Can the Free/Total PSA Ratio Predict the Gleason Score Before Prostate Biopsy?
}

\author{
Cavit Ceylan ${ }^{\mathrm{a}} \quad$ Eymen Gazel $^{\mathrm{a}} \quad$ İbrahim Keleş ${ }^{\mathrm{b}} \quad$ Ömer Doluoğluc Metin Yığman $^{\mathrm{a}}$
}

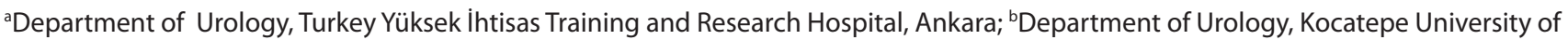
Medicine, Afyon; 'Department of Urology, Ankara Training and Research Hospital, Ankara, Turkey

\section{Key Words}

PSA • Percent free PSA prostate cancer • Gleason score • Prostate biopsy

\begin{abstract}
Objectives: To determine whether there is a correlation between high Gleason score and free/total ( $\mathrm{f} / \mathrm{t}$ ) prostate specific antigen (PSA) in patients newly diagnosed with prostate carcinoma. Materials and Methods: The study included 272 prostate biopsy patients whose total PSA value ranged from $4-10 \mathrm{ng} / \mathrm{ml}$. The patients were divided into 2 groups according to the f/t PSA ratio: Group $1 \leq 15 \%$ and Group $2>15 \%$. Furthermore, the groups were also compared to each other in terms of mild $(\leq 6)$, moderate $(=7)$, and high $(\geq 8)$ Gleason score. Results: Group 1 consisted of 135 (49.6\%) patients and Group 2 consisted of 137 (50.4\%) patients. While 27 (20\%) patients had a high Gleason score in Group 1, only 10 (7.3\%) patients had a high Gleason score in Group $2(p=0.008)$. Using Spearman's correlation test, we found that the $f / t$ PSA ratios were observed to decrease significantly in all patients with increased Gleason scores $(p=0.002, r=-0.185)$. Conclusion: According to our study, there is a relationship between higher Gleason score and decreased f/t PSA ratio. Therefore, $\mathrm{f} / \mathrm{t}$ PSA can be an indicator for predicting the Gleason score.
\end{abstract}

Copyright $\odot 2015$ S. Karger AG, Basel

\section{KARGER}

Fax +4161306 1234

E-Mail karger@karger.ch

www.karger.com
(C) 2015 S. Karger AG, Basel

1015-9770/14/0091-0024\$38.00/0

Accessible online at:

www.karger.com/cur

\section{Introduction}

Prostate carcinoma (PCa) is the most common occurring cancer type for men in the USA, and for elderly men in Europe [1,2]. It is the second most common cause of cancer-related death in men [1]. It is a serious health problem, especially in developed countries where the elderly population is proportionally higher [3]. Histopathological diagnosis of PCa can be established by transrectal ultrasound-guided (TRUS) biopsy after an abnormal finding in digital rectal examination or finding an augmentation in prostate specific antigen (PSA) level [3]. An increased PSA level is not specific for PCa; it can also elevate due to benign prostate hyperplasia, prostatitis, and other nonmalignant events [3]. Catalona et al. [4] suggests using a total PSA cut-off value of $4 \mathrm{ng} / \mathrm{ml}$ in order to recommend a prostate biopsy for diagnosing PCa. In numerous studies, the importance of free/total (f/t) PSA ratio was shown and this ratio is usually lower in patients with $\mathrm{PCa}$ than in those with benign prostate hyperplasia [5]. Catalona et al. [6, 7] suggest using a cut-off $f / t$ PSA ratio between $0.20-0.25$ be used for recommending evaluation to diagnose PCa. High Gleason scores also indicate a greater likelihood of PCa and correlate with increased total PSA levels $[8,9]$. Today, a $25 \%$ cut-off 
Table 1. Clinical and demographic characteristics of the patients

\begin{tabular}{llll}
\hline & $\begin{array}{c}\text { First group } \\
(\mathrm{n}=135)\end{array}$ & $\begin{array}{c}\text { Second group } \\
(\mathrm{n}=137)\end{array}$ & $\mathrm{p}$ \\
\hline Age (year) & $65.27 \pm 8.01$ & $66.04 \pm 7.55$ & 0.4 \\
Total PSA (ng/ml) & $7.02 \pm 1.94$ & $6.38 \pm 2.04$ & 0.008 \\
Free PSA (ng/ml) & $0.72 \pm 0.31$ & $1.37 \pm 0.61$ & $<0.001$ \\
Free/Total PSA & $0.1 \pm 0.03$ & $0.21 \pm 0.06$ & $<0.001$ \\
Prostate volume (ml) & $38.13 \pm 15.5$ & $45.37 \pm 20.01$ & 0.003 \\
Gleason score & $6.60 \pm 0.94$ & $6.35 \pm 0.8$ & 0.037 \\
\hline
\end{tabular}

First Group: free/total PSA $\leq 15 \%$; Second Group: free/total PSA $>15 \%$; PSA $=$ prostate specific antigen

Table 2. Mild, moderate and high-risk cancer distributions according to patients' Gleason score in Group 1 and Group 2

\begin{tabular}{llllll}
\hline & \multicolumn{1}{c}{$\begin{array}{c}\text { Mild } \\
(\text { Score } \leq 6)\end{array}$} & $\begin{array}{c}\text { Modarate } \\
(\text { Score }=7)\end{array}$ & $\begin{array}{c}\text { High } \\
(\text { Score } \geq 8)\end{array}$ & Total & p \\
\hline Group 1 & $88(65.2 \%)$ & $20(14.8 \%)$ & $27(20 \%)$ & 135 & \\
Group 2 & $100(73 \%)$ & $27(19.7 \%)$ & $10(7.3 \%)$ & 137 & \\
Total & $188(69.1 \%)$ & $47(17.3)$ & $37(13.6 \%)$ & 272 & 0.008 \\
\hline
\end{tabular}

$\mathrm{f} / \mathrm{t}$ PSA ratio for patients with total PSA levels between 4-10 $\mathrm{ng} / \mathrm{ml}$ (gray zone) is recommended for diagnosing $\mathrm{PCa}$. When this ratio is used, it has a $95 \%$ probability of correctly diagnosing PCa [10]. Also the f/t PSA ratio is useful for diagnosing more aggressive cancer and eliminating the need for redundant histopathological diagnoses $[11,12]$. In our study, we evaluated whether there is a correlation between the f/t PSA ratio and Gleason score in newly diagnosed PCa patients, and we evaluated the importance of using a $15 \%$ f/t PSA ratio cut-off value.

\section{Materials and Methods}

After receiving local ethics committee approval at our hospital, the data of 272 patients who received TRUS biopsies due to high PSA levels or suspicious findings during digital rectal examination and were diagnosed with PCa according to the outcome of biopsies, were evaluated retrospectively between the dates of January 2012 and December 2014. Twelve core TRUS biopsies were received from all patients whose total PSA levels were between $4-10 \mathrm{ng} / \mathrm{ml}$. Each biopsy was performed with the patient in the lateral decubitis position, and in all cases, an anesthetic block of the periprostatic plexus was applied by administering $0.2 \%$ prilocaine. A $25 \mathrm{~cm} 18$ gauge Tru-cut ${ }^{\circledR}$ needle was used in each case. The patients were divided into 2 groups according to f/t PSA ratio:

Importance of the Free/Total PSA Ratio
Group $1(\leq 15 \%)$ and Group $2(>15 \%)$. Ages, f/t PSA, prostate volumes, and Gleason scores of the groups were compared. Furthermore, the groups were compared with each other in terms of mild $(\leq 6)$, moderate $(=7)$, and high $(\geq 8)$ Gleason score.

The data analysis was performed by using SPSS for Windows, version 16 (SPSS Inc., Chicago, IL, United States). Descriptive statistics for variables with a normal distribution and categorical variables are shown as mean \pm standard deviation and the number of cases and percentage (\%), respectively. Student's t-test was used for the intergroup analysis of continuous variables, and $\mathrm{p}<$ 0.05 was accepted as statistically significant.

\section{Results}

Group 1 consisted of 135 (49.6\%) patients and Group 2 consisted of $137(50.4 \%)$ patients. The mean age in Group 1 was $65.2 \pm 8.01$ years and in Group 2 was 66.04 \pm 7.55 years $(\mathrm{p}=0.4)$. The prostate volumes of the patients in Group 1 and Group 2 were found as $38.13 \pm 15.5$ and $45.37 \pm 20.01 \mathrm{ml}$, respectively. The other comparative data for both groups are shown in table 1.

Patients from each f/t PSA group were further divided into 3 groups, low (score $\leq 6)$, moderate (score $=7$ ), and high (score $\geq 8$ ), according to their Gleason scores. A statistically significant difference was observed regarding PCa incidence between each f/t PSA group with high Gleason scores while there was statistically no significant difference between each $\mathrm{f} / \mathrm{t}$ PSA group with low and moderate-risk Gleason scores $(\mathrm{p}=0.601)$. While 27 patients $(20 \%)$ had high Gleason score in Group 1, the patient number in Group 2 was only $10(7.3 \%)(\mathrm{p}=0.008$, table 2).

Using Spearman's correlation test, we found that the f/t PSA ratios were observed to decrease significantly in relation to increased Gleason scores for all PCa patients $(p=0.002, r=-0.185)$.

\section{Discussion}

Partin nomogram, for indicating whether disease is organ-limited before radical surgery, was used as a guide in our studies [13]. Using the nomograms as a guide, we determined whether f/t PSA ratio has a correlation with Gleason score, or at least in patients with a high Gleason score. Previous studies have shown the clinical importance of a series of markers as well as tPSA for diagnosing $\mathrm{PCa}$, while also showing the clinical importance of $\mathrm{f} / \mathrm{t}$ PSA ratio for diagnosing PCa [14, 15]. Pannek et al. [16] emphasized in their study that the f/t PSA ratio can be of crucial predictive value for Gleason score. In similar 
studies, Noldus et al. [17] were unable to show the predictive significance of the $\mathrm{f} / \mathrm{t}$ PSA ratio in organ-limited disease. However, Sakai et al. [18] reported that the $f / t$ PSA ratio had a predictive significance for determining the PCa stage for patients in the gray zone between 4 $-10 \mathrm{ng} / \mathrm{ml}$ total PSA. Likewise, in our study, a significant negative correlation was detected between f/t PSA ratio and Gleason score. In another study from Turkey, Erdem et al. [19] were unable to show that the predictive significance of the f/t PSA ratio was more valuable than tPSA in patients who underwent radical prostatectomy. Southwick et al. [20] obtained results supporting our study. They emphasized that using a $15 \%$ cut-off value for $\mathrm{f} / \mathrm{t}$ PSA in patients with $<7$ Gleason scores improved prediction of T1c PCa. Morote et al. [21] determined a predictive cut-off value for f/t PSA ratio in T1c PCa pa- tients as $11 \%$, but then evaluated radical prostatectomy patients' data in their subsequent study and found that a $15 \%$ cut-off value for $\mathrm{f} / \mathrm{t}$ PSA ratio had greater predictive accuracy. Aus et al. [22] reported that in low-risk patients who underwent radical prostatectomy, those with $\mathrm{f} / \mathrm{t}$ PSA ratios that were $<10.7 \%$ had more aggressive $\mathrm{PCa}$. When the patients were divided into 2 groups according to $\mathrm{f} / \mathrm{t}$ PSA ratio, our study showed that patients below $15 \%$ (Group 1) had a higher Gleason score.

In conclusion, according to our study, $\mathrm{PCa}$ patients with higher Gleason score correlate with increased tPSA and decreased fPSA. Therefore, the f/t PSA ratio can be used for predicting the Gleason score. We believe that our work will be helpful for future research and may provide an impact for clinical considerations.

\section{References}

1 Siegel R, Ma J, Zou Z, Jemal A: Cancer statistics, 2014. CA Cancer J Clin 2014;64:9-29.

-2 Arnold M, Karim-Kos HE, Coebergh JW, Byrnes G, Antilla A, Ferlay J, Renehan AG, Forman D, Soerjomataram I: Recent trends in incidence of five common cancers in $26 \mathrm{Eu}-$ ropean countries since 1988: analysis of the European Cancer Observatory. Eur J Cancer 2015;51:1164-1187.

- 3 Heidenreich A, Bastian PJ, Bellmunt J, Bolla $\mathrm{M}$, Joniau $\mathrm{S}$, van der Kwast $\mathrm{T}$, Mason $\mathrm{M}$, Matveev V, Wiegel T, Zattoni F, Mottet N: EAU guidelines on prostate cancer. part 1: screening, diagnosis, and localtreatment with curative intent-update 2013. Eur Urol 2014; 65:124-137.

-4 Catalona WJ, Smith DS, Ratliff TL, Dodds KM, Coplen DE, Yuan JJ, Petros JA, Andriole GL: Measurement of prostate-specific antigen in serum as a screening test for prostate cancer. N Engl J Med 1991;324:1156-1161.

-5 Stenman UH, Hakama M, Knekt P, Aromaa A, Teppo L, Leinonen J: Serum concentrations of prostate specific antigenand its complex with a-1-antichymotrypsin beforediagnosis of prostatic cancer. Lancet 1994;344: 1594-1598.

6 Catalona WJ, Partin AW, Slawin KM, Brawer MK, Flanigan RC, Patel A, Richie JP, deKernion JB, Walsh PC, Scardino PT, Lange PH, Subong EN, Parson RE, Gasior GH, Loveland KG, Southwick PC: Use of percentage of free prostatespecificantigen to enhance differentiation of prostatecancer from benign prostatic disease: a prospective multicenter clinical trial. JAMA 1998;279:1542-1547.
7 Ito K, Yamamoto T, Ohi M, Kurokawa K, Suzuki K, Yamanaka H: Free/total PSA ratio is a powerful predictor offuture prostate cancer morbidity in men with initial PSA levels of 4.1 to $10.0 \mathrm{ng} / \mathrm{ml}$. Urology 2003;61:760-764.

$>8$ Thompson IM, Pauler DK, Goodman PJ, Tangen CM, Lucia MS, Parnes HL, Minasian LM, Ford LG, Lippman SM, Crawford ED, Crowley JJ, Coltman CA Jr: Prevalence of prostate cancer among men with a prostate-specificantigen level $<$ or $=4.0 \mathrm{ng}$ per milliliter. N Engl J Med 2004;350:22392246.

-9 Pelzer AE, Tewari A, Bektic J, Berger AP, Frauscher F, Bartsch G, Horninger W: Detection rates andbiologic significance of prostate cancer with PSA less than $4.0 \mathrm{ng} / \mathrm{ml}$ : observation and clinicalimplications from Tyrol screening project. Urology 2005;66:10291033.

10 Catalona WJ, Partin AW, Slawin KM, Brawer MK, Flanigan RC, Patel A, Richie JP, deKernion JB, Walsh PC, Scardino PT, Lange PH, Subong EN, Parson RE, Gasior GH, Loveland KG, Southwick PC: Use of the percentage of free prostate-specific antigen to enhance differentiation of prostate cancer from benign prostatic disease: a prospective multicenter clinical trial. JAMA 1998;279:1542-1547.

-11 Arcangeli CG, Humphrey PA, Smith DS, Harmon TJ, Shepherd DL, Keetch DW, Catalona WJ: Percentage of free serum PSA as a predictor of pathologic features of prostatic carcinoma in a screening population. Urology 1998;51:558-564.
-12 Pannek J, Rittenhouse HG, Chan DW, Epstein JI, Walsh PC, Partin AW: The use of percent free prostate-specific antigen for staging clinically localized prostate cancer. $\mathrm{J}$ Urol 1998;159:1238-1242.

13 Partin AW, Kattan MW, Subong EN, Walsh PC, Wojno KJ, Oesterling JE, Scardino PT, Pearson JD: Combination of prostate-specific antigen, clinical stage and Gleason score to predict pathological stage of localized prostate cancer. A multi-institutional update. JAMA 1997;277:1445-1451.

14 Haese A, Vaisanen V, Lilja H, Kattan MW, Rittenhouse HG, Pettersson K, Chan DW, Huland H, Sokoll LJ, Partin AW: Comparison of predictive accuracy for pathologically organ confined clinical stage T1c prostate cancer using human glandular kallikrein 2 and prostate specific antigen combined with clinical stage and Gleason grade. J Urol 2005; 173:752-756.

15 Anfossi E, Rossi D, Grisoni V, Sauvan R, Bladou F, Serment G: What is the role of the correspondence of free PSA/total PSA in staging of local prostate cancer? Series of 50 radical prostatectomy cases. Prog Urol 1999; 9:479- 482.

16 Pannek J, Subong EN, Jones KA, Marschke PL, Epstein JI, Chan DW, Carter HB, Luderer AA, Partin AW: The role of free/total prostate-specific antigen ratio in the prediction of final pathologic stage for men with clinically localized prostate cancer. Urology 1996;48 (6A suppl):51-54. 
17 Noldus J, Graefen M, Huland E, Busch C, Hammerer $\mathrm{P}$, Huland $\mathrm{H}$ : The value of the ratio of free-to-total prostate specific antigen staging purposes in previously untreated prostate cancer. J Urol 1998;159:2004-2007.

18 Sakai I, Harada K, Hara I, Eto H, Miyake H: Limited usefulness of the free-to-total prostate-specific antigen ratio for the diagnosis and staging of prostate cancer in Japanese men. Int J Clin Oncol 2004;9:64-67.
19 Erdem E, Atsu N, Akbal C, Bilen CY, Ergen A, Ozen H: The free-to-total serum prostatic specific antigen ratio as a predictor of the pathological features of prostate cancer. Int Urol Nephrol 2003;34:519-523.

20 Southwick PC, Catalona WJ, Partin AW, Slawin KM, Brawer MK, Flanigan RC, Patel A, Richie JP, Walsh PC, Scardino PT, Lange PH, Gasior GH, Parson RE, Loveland KG: Prediction of post-radical prostatectomy pathological outcome for stage T1c prostate cancer with percent free prostatatic specific antigen: a prospective multicenter clinical trial. J Urol 1999;162:1346-1351.
21 Morote J, Trilla E, Esquena S, Serrallach F, Abascal JM, Id H'Mammed Y, de Torres IM: Value of percent free prostate-specific antigen for the prediction of pathological stage in men with clinically localized prostate cancer. Int J Biol Markers 2002;17:239-243.

2222 Aus G, Becker C, Lilja H, Khatami A, Pihl CG, Hugosson J: Free-to-total prostate-specific antigen ratio as a predictor of non-organ-confined prostate cancer (stage pT3). Scand J Urol Nephrol 2003;37:466-470. 


\section{Erratum}

Unfortunately, an author name 'Omer G. Doluoglu' was written as 'Ömer Doluoğlu' by mistake in the paper by Ceylan et al.: Can the free/total PSA ratio predict the gleason score before prostate biopsy?. Curr Urol 2015;9:24-27. 